Ethiopian Journal of Environmental Studies \& Management 10(5): 597 - 609, 2017.

ISSN:1998-0507

doi: https://dx.doi.org/10.4314/ejesm.v10i5.4

Submitted: January 13, 2017

Accepted: June 12, 2017

\title{
EXTENSION SERVICE DELIVERY OF AGRICULTURAL DEVELOPMENT PROGRAMMES IN SOUTHWEST NIGERIA DURING THE POST WORLD BANK ERA (1996-2013)
}

\author{
*OLANIYI, A.A. AND FARINDE, A.J. \\ Department of Agricultural Extension and Rural Development, Obafemi Awolowo
} University, Ile-Ife, Nigeria

\begin{abstract}
The study was conducted to assess the extension service delivery within the Agricultural Development Programmes of Southwest Nigeria after the cessation of the World Bank funding between 1996 and 2013. Primary data were collected from 201 extension agents across $50 \%$ of the states in the area of study using structured questionaire. Descriptive statistical tools such as frequency counts, percentages, mean and standard deviation were used to analyse the data while t-test was used to test the hypothesis. Hypothesis tested revealed that significant difference existed in the level of extension service delivery in PWBE ( $\bar{X}=25.3$; Std. Dev=3.06) and WBE ( $\bar{X}=55.2$; Std. Dev= 7.0) with a t-value of (21) 2.241; $P \leq 0.055$. It was concluded that withdrawal of World Bank funding has grossly and negatively affected extension service delivery by the ADPs in Southwest, Nigeria. It is recommended that government at all levels should intensify effort in increasing the budgetary allocation to their extension organisations with a view to boosting food production among Nigerian farmers. Extension programme planners should explore the cooperative group farming approach to generate community level capitalization and also access funds for agricultural development from financial institutions and NGOs.
\end{abstract}

Key Words: Extension service, extension delivery, World Bank, Agricultural Development Programme

\section{Introduction}

Food security was hardly an issue of serious concern in the pre and immediate post independence Nigeria. This was because Nigeria was almost totally agrarian with over 70 percent of the population involved in agriculture which also constituted 65.7 percent of the Gross Domestic Product (GDP) (Encyclopedia of Nations, 2012). However, decline in agricultural production set in with the advent of the 'petroleum boom' of the 1970s. Attention shifted to the oil sector, leading to a situation where agriculture became progressively unattractive and the lure to the cities of farm workers was enhanced. From this period, food security became threatened as food production could no longer cope with the increasing population. At this point, Nigeria began to import food and equally lost its status of being a net exporter of some cash

*Corresponding Author: Olaniyi, A.A.

Email: jibloaolaniyi@yahoo.com 
crops that were regionally grown like cocoa in the western, oil palm in the eastern and ground nuts in the northern regions.

Concerted efforts were made by successive governments to address this ugly trend through some intervention programmes. According to Jibowo (2004), some of the agricultural programmes launched and executed by government included; National Accelerated Food Production Programme in 1973; River Basin Development Authority in 1975; Operation Feed the Nation launched in 1976; Green Revolution in 1980; Agricultural Development Programme conceived in 1972 but launched in 1975; the first National Fadama Development Project 1992; and National Special Programme for Food Security launched in 2003. None of this plethora of programmes has proven to be the antidote for the ailing food security situation in Nigeria.

A critical analysis of these programmes suggests that several extension approaches were used towards attaining increased agricultural productivity as reflected in the implemented projects already listed. Arokoyo (2011) worked extensively on the evolutionary trend of extension services delivery in Nigeria and identified about 10 major extension approaches and strategies used in the projects so far implemented. These included (i) The Colonial Commodity Extension Approach (ii) The Ministry of Agriculture approach (iii) The Revitalized Commodity Extension Strategy (iv) The farm settlement/Farm Institute Leavers' Extension Strategy (v) The National Accelerated Food Production Program (vi) Operation Feed the Nation (OFN) (vii) The River Basin Development Authority (RBDA) Strategies (viii) The Green Revolution (ix) The Pilot (Enclave) Agricultural Development Projects and (x) The Statewide ADP approach from 1984 to date. Despite the multiplicity of programmes and extension approaches used by Nigeria to tackle its food production problem, one programme has stood the test of time- the Agricultural Development Programme. The Agricultural Development Programmes (ADPs) were first launched as viable projects in 1972, only two years after the end of civil war, when Nigeria was facing its first food and fibre shock ( Auta and Dafwang, 2010)

However, despite the achievement of the ADP, some faults were identified among which were cost of financing, irrelevance and ineffectiveness and lack of equity. The continued relevance of the ADPs despite the avalanche of criticisms could not be divorced from the impact it made in raising yields of farmers and the fact that it had become the public sector provider of agricultural extension services in Nigeria as it is in each of the 36 states and the Federal Capital Territory. It is also a reservoir of a wide variety of professional hands in all sectors of agriculture nationwide.

Despite this, little or no studies have been conducted to empirically assess the organisation in the area of extension delivery effectiveness after the World Bank fund cessation in 1995 with a viewing to assessing the impact of the fund withdrawal in Southwest, Nigeria. Therefore, the study was conducted to assess level of extension delivery within the framework of the Agricultural 
Development Programme (ADP) after the cessation of the World Bank funding.

The objective of the study was to investigate the Extension service delivery of the ADPs and determine the level of extension service delivery after World Bank fund cessation in the study area. For this objective, a null hypothesis that there is no significant difference between extension service delivery before and after the World Bank fund cessation among the ADPs in the Southwest Nigeria was set.

\section{Methodology}

The study was conducted in Southwest, Nigeria. The region comprises six states: Lagos, Osun, Ogun, Ondo, Ekiti and Oyo. The population of the study comprised the ADPs extension and their supervisors. Multi-stage sampling procedure was employed to first select $50 \%$ of the states (Ogun, Osun and Ekiti) in the southwest region of Nigeria and also purposively select all extension agents and supervisors totalling 201 from the three States. A structured questionnaire was administered on the respondents while data analysis was carried out using descriptive statistics such as percentages, frequency count, and mean scores while t-test was used to test the hypothesis.

\section{Results and Discussion}

Selected Socio-Economic

\section{Characteristics of Respondents}

Age: Data in Table 1 showed that majority $(80.0 \%)$ of the extension agents and their supervisors were in the age group of 40- 49 years while only $20.0 \%$ were between 50 and 59 years. Osun $(28.2 \%)$ and Ekiti (26.5\%) States had more respondents in the age group of 50-
59 than Ogun State $(5.3 \%)$ indicating that Ekiti and Osun have older hands on the job than Ogun. This may indicate better experience on the job but may also indicate reduced agility compared to EAs in Ogun. The mean age was 51 years with a standard deviation of 7.6. Age , according to Alabi (2011), is one of the factors that could be used to measure people's level of maturity, strength and ability to accomplish tasks. Younger ages are characterized with hard work and zeal to achieve, while older ages have poor response to hard work. Extension agents who are in their active ages are more likely to be effective while carrying out their jobs on the field. The implication for extension service delivery is that the extension organization should be ready with a succession plan for the replacement of ageing extension workers so that a vacuum is not created when any old hand retires. This is however subject to prevailing government policy on recruitment as vacancies in civil service are more often than not frozen.For instance, Osun State ADP with an EA population of 214 at inception in 1992 downsized its staff in Year 2000 and there were no recruitment or replacement despite annual reduction due to retiement, death or resignation such that at the time of this study, only 29 EAs remain in post. This led to a skewed EA: Farmers ratio with negative consequencies on extention service delivery.

\section{Marital Status}

Table 1 showed that majority $(94.6 \%)$ of the respondents were married, 3.4 percent were widowed while only 2.0 percent were singles. That nearly all (98.0\%) had been married shows the importance attached to marriage in the study area. People who are married are 
usually perceived as being responsible and capable of stabilizing the home and society. The implication here is that as responsible married people, extension agents will most likely display maturity, good sense of duty and hard work thus delivering on targets set, hence performing better than the unmarried. That very few were widowed or widower also put them in an emotionally stable frame of mind to work with farmers. Furthermore, being all in their middle ages and married implied they were party to the conclusion of the World Bank Era with its successes and could make valid observations on the extension delivery of the Post World Bank Era.

Table 1: Distribution of Extension officers by their personal and socioeconomic characteristics

\begin{tabular}{lll}
\hline $\begin{array}{l}\text { Characteristics of } \\
\text { extension agents }\end{array}$ & $\begin{array}{l}\text { Total } \\
\mathrm{n}=201\end{array}$ \\
\hline Age & $\mathrm{F}$ & $\%$ \\
$40-49$ & 167 & 80.0 \\
$50-59$ & 34 & 20.0 \\
Mean & 51.03 & \\
Standard deviation & 7.6 & \\
Marital status & & \\
Married & 190 & 94.6 \\
Singles & 4 & 2.0 \\
Widowed & 7 & 3.4 \\
\hline
\end{tabular}

\section{Household Size}

Results in Table 2 showed that many $(56.3 \%)$ extension agents had households with 4-6 members, while about $37.1 \%$ had more than 6 members. Only very few $(6.6 \%)$ extension agents had less than 4 household members. The mean household size was 4.38 while the standard deviation was 1.23 . The finding agrees with Ibitunde (2013) who reported a mean household size of 4.34 and standard deviation of 2.07 for extension agents in Osun state. The implication of small household for extension agents on extension delivery is that extension agents will be able to give adequate care in terms of feeding, health and education to his children and equally concentrate on extension work.

\section{Educational Level}

Results in Table 2 showed that many (52.6\%) extension agents and their supervisors possessed HND qualification or its equivalent (B.Sc.) while some $(45.9 \%)$ possessed NCE or OND. Only a few $(1.5 \%)$ of the respondents had postgraduate education. This finding shows that the States in the study area recruited qualified hands to perform the job of extension delivery. The finding also corroborates Madukwe (2008), that in terms of capabilities, the majority of field extension staff had general training in agriculture with sub-degree qualification such as the Ordinary National Diploma (OND) and Higher National Diploma (HND) as their highest academic qualification. More recently, holders of the bachelor degree have been recruited as extension agents. The implication is that hiring of capable hands results in good extension delivery on the field. Training time at FNTs by SMSs also gets reduced as extension agents have sound educational foundations. However, the issue of career progression in civil service should be considered so that prospects for promotion of each cadre of staff are not jeopardized.

\section{Field of Specialization}

Data in Table 2 showed that some $(30.8 \%)$ of the extension officers specialized in General Agriculture, 23.9\% studied Animal production while $18.6 \%$ specialized in Agric. Econ/ 
extension and another $17.3 \%$ specialized in agronomy. The implication is that extension officers being sub-graduates of agriculture themselves, will find it easier to understand any technological information coming from the subject matter specialists at the FNTs and will equally find it easy to deliver such to farmers on the field. This will aid the practice of Unified Agricultural Extension Service.

Table 2: Distribution of extension agents by their personal and socio-economic characteristics

\begin{tabular}{|c|c|c|c|c|}
\hline $\begin{array}{ll}\text { Characteristics } & \text { of } \\
\text { agents } & \end{array}$ & extension & \multicolumn{2}{|c|}{$\begin{array}{l}\text { Total } \\
n=201\end{array}$} & $\begin{array}{l}\text { Mean } \\
\pm \text { S.D }\end{array}$ \\
\hline Household size & & $\mathrm{F}$ & $\%$ & \\
\hline Below 4 & & 13 & 6.6 & \\
\hline $4-6$ & & 120 & 56.3 & \\
\hline Above 6 & & 68 & 37.1 & $4.38 \pm 1.23$ \\
\hline Educational level & & & & \\
\hline NCE/OND & & 90 & 45.9 & \\
\hline HND/B.Sc & & 110 & 52.6 & \\
\hline M.Sc & & 3 & 1.5 & \\
\hline Field of specialization & & & & \\
\hline Agric. Econ/Extension & & 39 & 18.6 & \\
\hline Agronomy & & 40 & 17.3 & \\
\hline Animal Production & & 48 & 23.9 & \\
\hline Soil science & & 13 & 6.0 & \\
\hline General Agric & & 52 & 30.8 & \\
\hline Others & & 9 & 3.4 & \\
\hline
\end{tabular}

\section{Level of Extension Service Delivery}

Table 3 shows that there was a general decline in extension service perfomance along the list of deliverables examined. While there was 29 percent increase in the number of registered farmers during the PWBE, Contact farmers registered dropped by 19 percent.This may not be unconnected with the rigorous criteria for selecting them which required that EAs get very close and familiar with famers in his cell to discover his/her outstanding characteristics which will qualify him /her for selection. Such activities may become cumbersome for an EA as number of cells covered increases (as obtained in PWBE where an EA covered more than the mandatory 1 cell ) hence the observed decline. The number of extension agents in service during the PWBE dropped by 54.3 percent to the figure in post during the WBE. This was due to mass retrenchment and nonreplacement of retired staff by many State Governments as a result of the inability of owner states to maintain the standards that prevailed during the WBE. This confirms the assertion of Madukwe (2008) that the report of good performance of the ADPs lasted as long as the World Bank loan facility lasted and that the Federal, State and Local Governments have proved incapable of financing the ADP extension system in Nigeria. So also the findings revealed 
that there were declines in other deliverables such as MTRM conducted (30\%), SPATs established $(72.7 \%)$, FNTs conducted $(7.1 \%)$ and Functional Farm service centres (60\%). Of more severity and with devastating effect was the decline in the Extension Agent: Farmers ratio which fell by as much as 340 per cent, from 1:1605 in the WBE to 1:5500 in the PWBE. As availability of functional or serviceable motorcycles for EAs reduced by 38.5 percent, so also Farm visit declined by 58 percent during the PWBE.

Staff strength declined from 563 in the WBE to $233(58.6 \%)$ during the PWBE reflecting the inability of states to meet up with the demands of $\mathrm{T} \& \mathrm{~V}$ System of Extension. However, advocacy progragrammes increased from 135 during the WBE to $165(20.7 \%)$ in the PWBE, probably to make for deficiency of field hands. The meeting of the Governing Board of ADPs, ADPEC showed lack of committment to extension services by owner States. While Osun had 4 meetings per year during the WBE and none during the PWBE, Ogun had no meetings throughout the lifetime of the ADP. Ekiti had ADPEC meetings only 4 times during the PWBE. These findings corroborate the assertion of Ogunlade $e t$ al. (2009) that after the stoppage of World Bank's support in 1995, most of the ADPs have been unable to cope with their primary responsibilities of providing agricultural extension services in their domain. 
Table 3: Extension Service Performance in the Study Area (1995- 2013)

\begin{tabular}{|c|c|c|c|c|c|c|c|c|c|c|}
\hline \multirow[t]{2}{*}{ S/No } & \multirow[t]{2}{*}{ INDICATORS } & \multicolumn{2}{|c|}{ OGUN STATE } & \multicolumn{2}{|c|}{ OSUN STATE } & \multicolumn{2}{|c|}{ EKITI STATE } & \multicolumn{2}{|c|}{ MEAN VALUE } & \multirow[t]{2}{*}{$\%$ DIFF } \\
\hline & & WBE & PWBE & WBE & PWBE & WBE** & PWBE & WBE & PWBE & \\
\hline 1 & Farm families registered & 260,000 & 360,000 & 249,508 & 254,984 & 123,000 & 200,000 & 210,836 & 271,661 & 29.0 \\
\hline 2 & Contact farmers & 8880 & 7200 & 7817 & 4289 & 6400 & 7200 & 7697 & 6230 & 19.0 \\
\hline 3 & No of Extension Agents & 120 & 90 & 214 & 26 & 80 & 73 & 414 & 189 & 54.3 \\
\hline 4 & MTRM Conducted & 11 & 4 & 11 & 8 & 11 & 11 & 11 & 7.7 & 30.0 \\
\hline 5 & SPATs/year & 11,784 & 5239 & 9290 & 109 & 1555 & 826 & 7543 & 2058 & 72.7 \\
\hline 6 & FNTs/year & 22 & 23 & 26 & 24 & 26 & 22 & 24.7 & 23 & 7.1 \\
\hline 7 & Functional Service centre's & 4 & 4 & 57 & 21 & 0 & 0 & 20 & 8 & 60.0 \\
\hline 8 & EA: Farmer ratio & $1: 2116$ & $1: 4000$ & $1: 1165$ & 1:9807 & $1: 1537$ & $1: 2740$ & 1:1606 & $1: 5516$ & 343. \\
\hline 9 & Functional motorcycles & 104 & 70 & 205 & 29 & 80 & 142 & 130 & 80 & 38.5 \\
\hline 10 & Field Days/year & 38 & 76 & 13 & 7 & 15 & 17 & 22 & 33 & 50.0 \\
\hline 11 & Farm visits & NA & NA & 27,902 & 3784 & 13250 & 13410 & 20576 & 8597 & 58.2 \\
\hline 12 & Staff strength & NA & NA & 725 & 156 & 400 & 310 & 563 & 233 & 58.6 \\
\hline 13 & Radio programmes & NA & NA & 13 & 37 & 260 & 288 & 135 & 163 & 20.7 \\
\hline 14 & ADPEC meetings & NA & NA & $4 / \mathrm{yr}$ & 0 & NIL & $\begin{array}{l}\text { 4in } 18 \\
\text { yrs }\end{array}$ & Var & Var & \\
\hline
\end{tabular}

PWBE $=$ Post World bank Era

$\mathrm{WBE}=$ World Bank Era 


\section{Funding of Extension Services in the Study Area}

Data in Table 4 show that a sum of N350,497,000 was received by the ADPs in the study area during the WBE (19891995) from the World Bank but declined to N172 million during the PWBE(19962013). Though the Federal and State Governments stepped up their counterpart funding during the PWBE, but the economic depression of the 1980s has resulted in double digit inflation since the introduction of SAP. This according to Jayeoba (2008) led to a depletion of of real income, making norminal earning grossly inadequate to meet daily needs of workers. This resulted in upgrades in minimum wages in 1997, 1999 and 2011 respectively. These wage increases for public sector workers may be responsible for the observed increases in FGN and State Government funding in the PWBE and not necessarily monies spent for field level extension activities. The unavailability of further funding from the WB and increasing budget needs of the ADPs created sustainability challenges leading to staff retrenchment in many states. This confirmed the assertion of Ogunlade et al. (2009) that many ADPs developed coping strategies such as staff reduction, irregular Monthly Technology Review Meetings (MTRM) and reduced number of forth night training (FNT), and were still unable to cope.
The dearth of funds from the WB and FGN for the ADPs' direct extension activities continued unabated in the PWBE. However, attention shifted to other donor -funded projects which were pushed to the ADPs to implement. These projects had specific targets and goals and were not for ADP extension services. Over eight (8) of such projects were handled by the ADPs in the study area during the PWBE, thus becoming the major source of funds receivable. A sum of N24,979,000.25 was received from Federal Government sponsored projects by the ADPs (as listed in Table 4 below) during the WBE while N5,883,237,000 was received by the ADPs in the area of study during the PWBE. This shows the heavy reliance of the ADPs on Federal and external funds which were directed at implementing specific projects and not the ADPs'core activities. This also confirms the report of Mogues et al. (2008) that ADPs despite being state institutions rely heavily on Federal and external funds. Therefore, when WB and Federal Government funds cease, extension activities relying on state's meagre funding are negatively affected. The finding also agrees with Ammani et al. (2010) that funding was the major problem of the ADPs since the tripartite funding arrangement between the World Bank, Federal Government and State Government ceased in 1995. 
Table 4: Funding of Extension Services in the Study Area (1995 - 2013)

\begin{tabular}{|c|c|c|c|c|c|c|c|c|c|}
\hline \multirow[t]{2}{*}{ S/No } & \multirow{2}{*}{$\begin{array}{l}\text { INCOME } \\
\text { SOURCES }\end{array}$} & \multicolumn{2}{|c|}{ OGUN STATE ('000) } & \multicolumn{2}{|c|}{ OSUN STATE ('000) } & \multicolumn{2}{|c|}{ EKITI STATE ('000) } & TOTAL & $(' 000)$ \\
\hline & & WBE & PWBE & WBE & PWBE & $\mathrm{WBE}^{* *}$ & PWBE & WBE & PWBE \\
\hline 1 & $\begin{array}{l}\text { WORLD } \\
\text { BANK }\end{array}$ & $160,568.0$ & $33,092.0$ & 189,929 & 131,263 & - & $7,480.0$ & 350,497 & 171,835 \\
\hline 2 & $\begin{array}{l}\text { FEDERAL } \\
\text { GOVT }\end{array}$ & $20,377.00$ & $199,615.0$ & 12,772 & 23,562 & - & $55,570.0$ & 33,149 & 278,747 \\
\hline 3 & $\begin{array}{l}\text { STATE } \\
\text { GOVT }\end{array}$ & $55,849.00$ & $2,824,689.0$ & 90,338 & $1,935,344$ & - & $1,523,500.0$ & 146,187 & $6,283,533$ \\
\hline 4 & LGA & 0 & 0 & 0 & 0 & - & $35,300.0$ & 0 & 35,300 \\
\hline 5 & IGR & 60.0 & $2,580.0$ & 35,921 & 34,163 & - & $3,130.0$ & 35,981 & 39,873 \\
\hline 6 & IFAD & $24,740.00$ & $53,113.0$ & 0 & 0 & - & $32,150.0$ & 24,740 & 85,263 \\
\hline 7 & IITA/CBN & 64.25 & $3,995.00$ & 0 & 0 & - & 0 & 64.25 & 3,995 \\
\hline 8 & FADAMA I & 175 & 0 & 0 & 20,000 & - & 754.0 & 175 & 20,754 \\
\hline 9 & RTEP & 0 & $10,343.0$ & 0 & 54,164 & - & $33,700.0$ & 0 & 98,207 \\
\hline 10 & NPFS & 0 & $84,377.0$ & 0 & 233,169 & - & $710,200.0$ & 0 & $1,027,746$ \\
\hline 11 & FADAMA II & 0 & $923,000.0$ & 0 & 0 & - & 0 & 0 & 923,000 \\
\hline 12 & FADAMA III & 0 & 615,000 & 0 & $1,062,391$ & - & $1,237,650.0$ & 0 & $2,915,041$ \\
\hline 13 & NDIC & 0 & 0 & 0 & 1,014 & - & 0 & 0 & 1,014 \\
\hline 14 & SASAKAWA & 0 & 0 & 0 & 0 & - & $776,054.0$ & 0 & 776,054 \\
\hline 15 & FFS & 0 & 0 & 0 & 0 & & 31,400 & 0 & 31,400 \\
\hline \multirow[t]{2}{*}{16} & NATSP & 0 & 0 & 0 & 0 & & 763.0 & 0 & 763.0 \\
\hline & TOTAL & $261,833.25$ & $4,749,804$ & 328,960 & $3,495,070$ & & $4,447,651$ & 294793.25 & $12,692,525$ \\
\hline
\end{tabular}

** Ekiti State was created in October 1996 


\section{Test of Hypothesis}

The hypothesis tested for the study was in the null form

There is no significant difference in the level of extension delivery before and after World Bank fund cessation in Southwest, Nigeria

Results of t-test analysis in Table 5 showed that there was a significant difference in the level of extension service delivery generally in the PWBE
$(\bar{X}=2.508 \mathrm{E} 3 ;$ Std. Dev=3.06E3) and WBE $(\bar{X}=5.517 \mathrm{E} 3$; Std. Dev= 7.003E3) with a t-value of $(22)-2.241 ; \mathrm{P} \leq 0.055$. The findings showed that there was a significant difference in the level of extension service delivery between the World Bank Era and the Post World Bank Era when examined wholistically at 0.05 level of significance.

Table 5: Results of t-test analysis showing the differences between extension service delivery before and after the World Bank fund ceasation

\begin{tabular}{llllcl}
\hline Variable & Mean & Std. Dev & Std. Error & T & P-value \\
\hline Extension service delivery in PWBE & 25.08 & $3.006 \mathrm{E} 3$ & $1.002 \mathrm{E} 3$ & 2.241 & 0.055 \\
Extension service delivery in WBE & 55.17 & $7.003 \mathrm{E} 3$ & $2.344 \mathrm{E} 3$ & & \\
\hline
\end{tabular}

Table 6 shows that individual extension delivery parameters such as number of contact farmers per EA (3.489); number of EAs (3.139); number of vacant cells (3.785); number of fertilizer drop points (2.252); number of MTRM held/year (3.457); number of SPAT established (2.433), number of extension coverage areas, farmers to extension agent ratio (3.913) and number of FNTs held/year (8.196) before and after the World Bank funding cessation were significantly different. The finding agreed with Oladele (2004) that there was a sharp decline in extension activities after loan withdrawal. 
Table 6: Summary of t-test analysis showing detailed differences between extension service delivery before and after World Bank fund withdrawal using key extension delivery indicators

\begin{tabular}{|c|c|c|c|c|c|c|c|c|}
\hline \multirow[t]{2}{*}{ Variable } & \multicolumn{5}{|c|}{ Paired Differences } & \multirow[t]{2}{*}{$\mathrm{t}_{\mathrm{Cal}}$} & \multirow[t]{2}{*}{$\mathrm{t}_{\mathrm{Tab}}$} & \multirow[t]{2}{*}{ Decision } \\
\hline & Mean & $\begin{array}{l}\text { Standard } \\
\text { Deviation }\end{array}$ & $\begin{array}{l}\text { Standard error } \\
\text { mean }\end{array}$ & $\begin{array}{l}95 \% \text { Confidence In } \\
\text { Mean }\end{array}$ & rval of & & & \\
\hline $\begin{array}{l}\text { 1. No of contact farmers / EA } \\
\text { in WB vs PWB era }\end{array}$ & 287.327E3 & 258.32189 & 667.38055 & -3720.70286 & -936.44000 & -3.489 & & $\mathrm{~S}$ \\
\hline $\begin{array}{l}\text { 2. No of EAs in WB vs PWB } \\
\text { era }\end{array}$ & $6.98333 \mathrm{E} 1$ & 94.37862 & 22.24525 & 22.89995 & 116.76672 & 3.139 & & $\mathrm{~S}$ \\
\hline $\begin{array}{l}\text { 3. No of vacant cells in WB vs } \\
\text { PWB era }\end{array}$ & 18.06000E1 & 82.46714 & 21.29292 & -126.26878 & -34.93122 & -3.785 & & $\mathrm{~S}$ \\
\hline $\begin{array}{l}\text { 4. No of fertilizer drop point } \\
\text { wb vs pwb }\end{array}$ & 5.85714 & 11.91757 & 2.60063 & .43233 & 11.28196 & 2.252 & & S \\
\hline $\begin{array}{l}\text { 5. No of MTRM held/yr wb vs } \\
\text { pwb }\end{array}$ & 41.63333E1 & 20.04700 & 4.72512 & -26.30247 & -6.36419 & -3.457 & 1.984 & $S$ \\
\hline $\begin{array}{l}\text { 6. No of REFILS held wb vs } \\
\text { pwb }\end{array}$ & 1.66667 & 1.84710 & .43536 & -1.58521 & .25187 & -1.531 & & NS \\
\hline 7. No of FNT held wb vs pwb & 9.83333 & 5.09036 & 1.19981 & -12.36471 & -7.30196 & -8.196 & & $S$ \\
\hline $\begin{array}{l}\text { 8. Average no of SPAT } \\
\text { set/annum } w b-p w b\end{array}$ & 4.05000E2 & 0.61099 & 16.64317 & 5.38598 & 75.61402 & 2.433 & & $\mathrm{~S}$ \\
\hline $\begin{array}{l}\text { 9. No of service centres with } \\
\text { sales officers wb vs pwb }\end{array}$ & 11.14286 & 12.67393 & 2.76568 & -6.91196 & 4.62625 & -.413 & & NS \\
\hline $\begin{array}{l}\text { 10. No of cells covered by EA } \\
\text { in WB era vs PWB era }\end{array}$ & $52.10000 \mathrm{E} 1$ & 2.10854 & 11.37102 & -2.71952 & 44.71952 & 2.847 & & S \\
\hline $\begin{array}{l}\text { 11. EA: farmers ratio in WB } \\
\text { vs PWB era }\end{array}$ & $1.92000 \mathrm{E} 4$ & 14.5921 & 9.1845 & -1.8439 & 13.9826 & 3.913 & & $S$ \\
\hline
\end{tabular}




\section{Conclusion and Recommendations}

Based on the major findings, majority of the extension agents and their supervisors were males, married and with a mean age of 51years. It was evident that extension personnel in the study area are highly literate and experienced . Level of extension delivery from the extension personnel perspective was low in post World Bank era compared to what obtained during the World Bank era. This was confirmed by the signifcant difference existing between extension delivery in the World Bank and post-World Bank era with significant changes in the agricultural extension service parameters.

It was therefore recommended that:

1. the three tiers of government should collaborate in addressing the funding deficiencies plagueing the only public agricultural extension organization (ADPs) with a view to boosting extension service delivery in Nigeria pending the time extension is either privatised or becomes a PublicPrivate-Partnership. A PPP arrangement, where the Government, Farmers in Commodity Cooperatives and Agro-allied Industries will partner (at pre-agreed percentages) to shares cost of services is suggested.

2. extension programme planners should explore cooperative group farming arrangements to facilitate community level capitalization and enhance easy access to funding from financial institutions and NGOs. This would equally aid the gradual evolution of extension service into being made demand driven.

\section{References}

Alabi, D.L. (2011). Analysis of Factors influencing Effective Management of Rural Household Enterprises in Osun State. Ph.D Thesis, Department of Agricultural Extension and Rural Development, Obafemi Awolowo University, Ile-Ife, Nigeria. Pp7273

Ammani, A.A., Auta, S.J. and Aliyu, J.A. (2010). Challenges to Sustainability: Applying the problem Tree Analysis Methodology to the ADP System in Nigeria. Journal of Agricultural Extension, 14(2): 35-45.

Arokoyo, T. (2011). ICTs in the Transformation of Agricultural Extension: The Case of Nigeria. A monograph, pp25

Auta, S.J. and Dafwang, I.I. (2010). The Agricultural Development Projects (ADPs) in Nigeria: Status and Policy Implications. Research Journal of Agriculture and Biological Sciences, 6(2): 138-143.

Encyclopedia of The Nations (2013). Nigeria - $\quad$ Agriculture http://www.nationsencyclopedia.co m/economies/Africa/NigeriaAGRICULTURE.html\#ixzz2QuE0 gZUy.9pp

Madukwe, M.C. (2008). Practice without Policy: The Nigerian Agricultural Extension Service: An Inaugural Lecture of the University of Nigeria, Nsukka delivered April 29, 2008 pp76 Accessed 12/04/14

Mogues, T., Morris, M., Freinkman, L., Adubi, A., Ehui,S., Nwoko, C., Taiwo, O., Nege, C., Okonji, P. and Chete, L. (2008). Agricultural Public Spending in Nigeria, 
International Food Policy Res Institute.

http://www.ifpri.org/publications/ag ricultural-public-spending-nigeria. Accessed5/6/14

Ibitunde, I.O. (2012). Assessment of the extent and effective use of ICT in agricultural extension service delivery in Osun State, Nigeria. An M. Sc Thesis, Department of Agricultural Extension and Rural Development, OAU. Ile-Ife, Nigeria. p76

Jibowo, A.A. (2004). Introduction to Research in Agricultural Extension: Research Methods in Agricultural Extension Agricultural Extension Society of Nigeria.
Ogunlade, I., Oladele. O.I. and Babatunde, O.A. (2009). Farmers' Attitude to Beneficiary Funding of Extension Services in Kwara State Nigeria. J. Hum. Ecol., 26(3): 215220.

Oladele, O.I. (2004). Effect of World Bank Loan Withdrawal on the Performance of Agricultural Extension in Nigeria. Nordic Journal of African Studies, 13(2): 141-145.

Jayeoba, F.I. (2012). Wage Trend in Nigeria: Historical Perspectives and Factors. Labour Law Review NJLIR Vol.6 No3, 2012 pp63-85. 